\title{
CARBONIFEROUS TO TERTIARY DEVELOPMENT OF THE WANDEL SEA BASIN, EASTERN NORTH GREENLAND
}

\author{
Eckart Håkansson
}

This paper presents a report on the first systematic mapping in the northern half of the Wandel Sea Basin carried out in 1978. Due to unfavourable weather conditions along the north-east coast of Peary Land, only 20 days of actual fieldwork were achieved. The Wandel Sea Basin comprises a series of Carboniferous to Paleocene rocks in eastern North Greenland (Dawes \& Soper, 1973). Previous visits to the northern part of the basin have been very brief (Koch, 1929a; Troelsen, 1950, 1956; Håkansson \& Heinberg, 1977) and only in the southern part is the basin known in any detail (Dawes, 1976).

A composite sequence of sediments exceeding $3500 \mathrm{~m}$ was recorded in eastern Peary Land, the 'Prinsesse Øer', and the northern part of Kronprins Christian Land (fig. 25). As expected, this sequence shows an overall resemblance to comparable strata of the same age in Svalbard (e.g. Harland, 1969), particularly in the lower part, but precise comparisons await detailed biostratigraphical investigations. Nine lithostratigraphical formations and two groups are established here, but no members have been defined.

In eastern Peary Land the sediments of the Wandel Sea Basin occur mainly in the Kim Fjelde area (fig. 26). A few minor occurrences have been recorded in Wyckoff Land further to the north-west. The geological structure of the Kim Fjelde is reflected in the characteristic, often cuesta-like, landscape with parallel, elongate hills reaching a maximum height of $900 \mathrm{~m}$ in the north (Henry Parish Bjerg). Towards the south there is a general decrease in height and considerable areas are made up of plateaus or low, rolling hills. Along the north-eastern margin, the Kim Fjelde are bordered by a broad low lying plain with a continuous cover of Quaternary sediments (fig. 26).

Typically the hills and plateaus are extensively covered with debris, and good exposures are thus rare. However, the cover is most often locally derived, or even weathered out in situ. Very little exotic material has been found within the Kim Fjelde.

\section{Stratigraphy \\ Mallemuk Mountain Group \\ (map 1, fig. 26), new group}

In eastern Peary Land rocks of the Wandel Sea Basin rest with regional unconformity on a variety of rocks from the Franklinian fold belt. The lower parts of the Wandel Sea Basin sequence in particular display marked lateral variations and include conglomerates and 


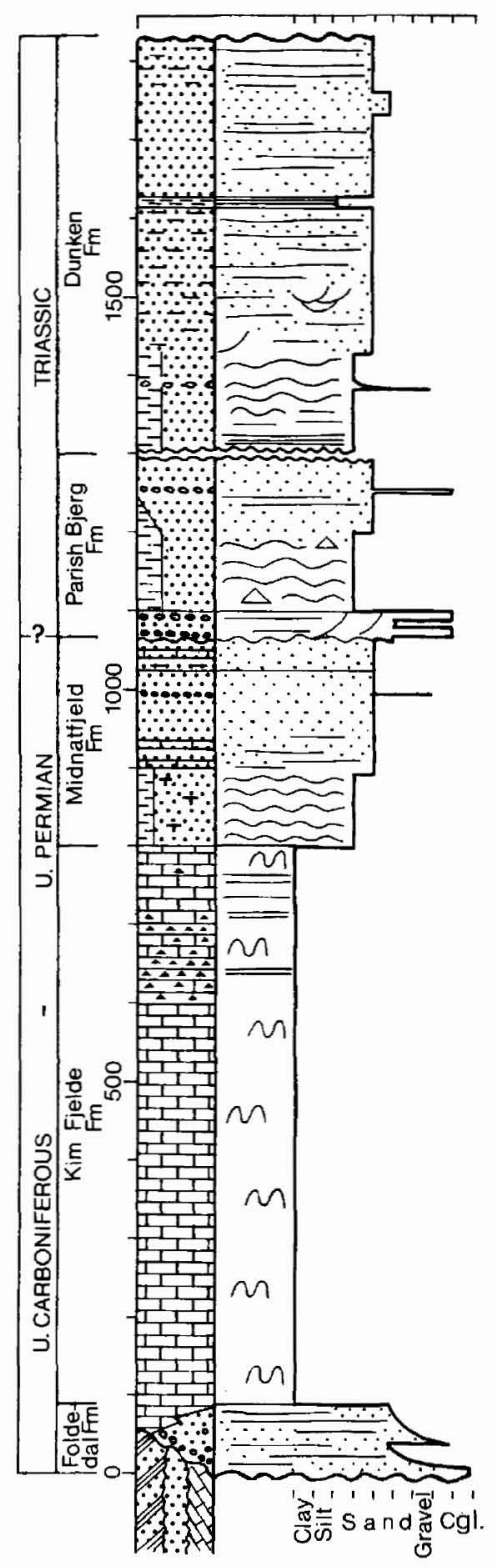

Fig. 25. Composite lithological sequence in the northern part of the Wandel Sea Basin. Based on profiles measured in eastern Peary Land in 1976 (Håkansson \& Heinberg, 1977) and 1978, as well as on Prinsesse Thyra $\emptyset$ and Nakkehoved during 1978.

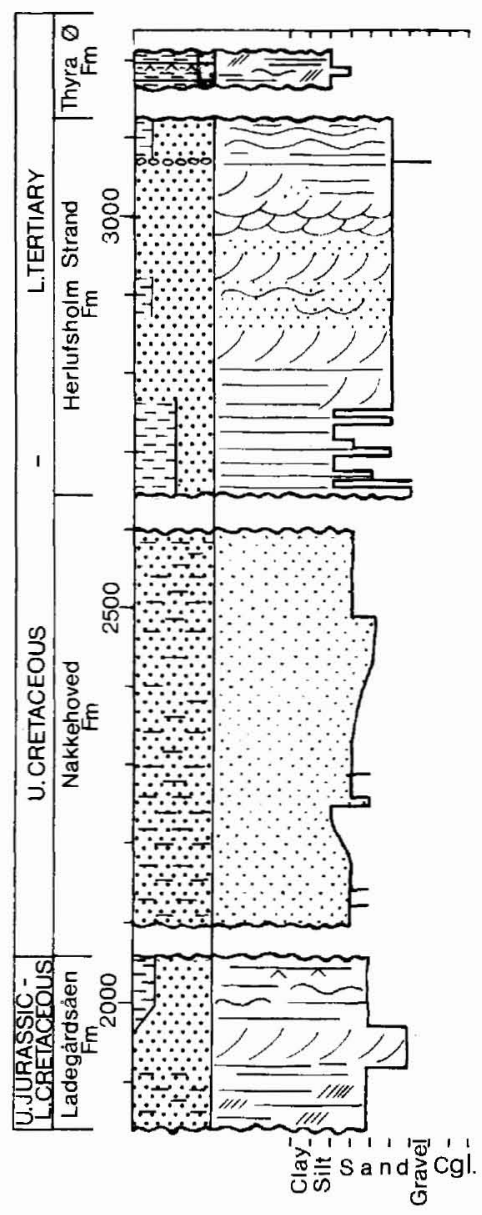

sandstones in red-bed facies as well as grey limestones and cherts. These may be distinguished as two formations. However, Koch (1929b) undoubtedly included all these rocks in the Mallemuk Mountain Formation, which he based mainly on descriptions from Holm Land and Amdrup Land where the Mallemuk Mountain Formation comprises a Carboniferous to Lower Permian sequence approximately $1100 \mathrm{~m}$ thick composed of varied carbonates with subordinate sandstones and a few evaporites (Grönwall, 1917; E. Nielsen, in Frebold, 


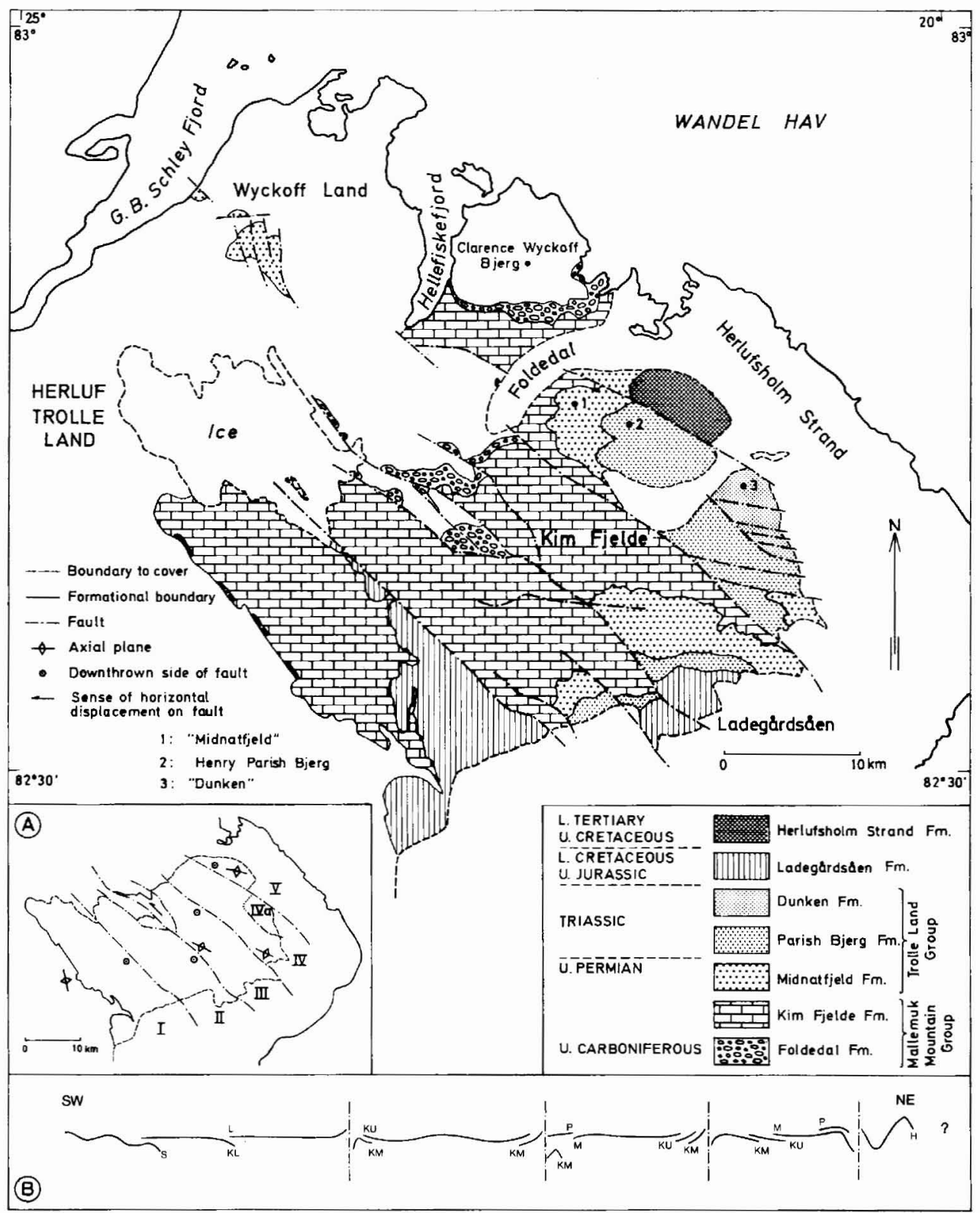

Fig. 26. Provisional lithostratigraphic map of the Kim Fjelde region, eastern peary Land. The inset map A outlines the major fault blocks and their relative movement as indicated by the distribution of the Foldedal Formation and the drag fold symmetry. $\mathbf{B}$ is a simplified structural profile normal to the faults. H: Herlufsholm Strand Formation; L: Ladegårdsåen Formation; D: Dunken Formation; P: Parish Bjerg Formation; M: Midnatfjeld Formation; K: Kim Fjelde Formation; (lower (KL \& KM) and upper (KU) part); F: Foldedal Formation; S: Silurian turbidites. 
1950). On the basis of more detailed information now available from Peary Land the status of this unit is raised to a group, which can be subdivided into two formations in eastern Peary Land and which includes the as yet undivided rocks in the vicinity of Station Nord as well as the classic areas in Holm Land and Amdrup Land.

\section{Foldedal Formation}

(map 1, fig. 26), new formation

(Named after the valley Foldedal bordering Kim Fjelde to the west)

This formation includes the highly variable, mainly clastic rocks which form the base of the Wandel Sea Basin sequence near its north-western margin around Foldedal and Clarence Wyckoff Bjerg. The basal part is composed of red beds and commonly begins with a conglomerate consisting of angular to subangular blocks in a coarse-grained, poorly sorted sandy matrix. This grades up into variable sandstones or sandy limestones with additional conglomerates. Fossils found particularly in the limey intervals include solitary and colonial rugose corals, chaetetids, and productid brachiopods, which indicate marine conditions.

A generally very light weathering series of light brown to almost white sandstones with some distinct grey limestone beds is found in the upper part of the Foldedal Formation. The limestones contain orange to red chert in lenses and irregular nodules as well as silicified marine faunas composed of brachiopods and colonial rugose corals.

The thickness of the Foldedal Formation varies considerably. The maximum thickness measured is $208 \mathrm{~m}$, but due to variation in basement relief it is estimated that the formation is at least twice as thick as near the coast north of Foldedal (J. Ineson, personal communication, 1978). From here it thins rapidly so as to be absent or perhaps very thin towards the west and south-west where rocks of the overlying Kim Fjelde Formation and Midnatfjeid Formation apparently rest directly on the Franklinian basement.

At Hellefiskefjord a thin sequence of red beds seemingly underlies rocks of the Kim Fjelde Formation which have yielded microfossils of Late Pennsylvanian (Late Virgilian?) age (Petryk, 1977). In combination with the general character of the macrofauna this points to a Late Carboniferous age for the entire Foldedal Formation.

\section{Kim Fjelde Formation}

(fig. 26), new formation

(Named after the mountainous area Kim Fjelde)

The Kim Fjelde Formation comprises a series of limestones showing marked lateral variation in both thickness and lithology. No single complete section is available but the total thickness is believed to exceed $750 \mathrm{~m}$.

Two lithological units may be distinguished:

(1) The lower unit is composed of limestones with less than 50 per cent chert. A sequence of more than $185 \mathrm{~m}$ of light grey bioclastic limestones with very abundant fusulinids in distinct horizons is succeeded by at least $230 \mathrm{~m}$ of fairly dark grey, fine-grained limestones. Well preserved macrofossils are common only in the dark, fine-grained part and include brachiopods (spiriferids, productids, and rhynchonellids), some bryozoans (stenoporid trepostomes), solitary rugose corals and a few gastropods. This unit probably includes the rocks from Hellefiskefjord referred to by Peel et al. (1974, p. 20). 
(2) The upper unit is dominated by light grey limestones and dark, calcareous shales with a very high content of chert. Typically the sequence begins with a fairly thin interval of bioclastic (commonly crinoidal) limestone rich in chert. This lithology is rapidly succeeded by shaly, finer-grained limestones with little more than 50 per cent chert in the west and light chert interbedded with dark cherty, calcareous shale in the east. In these upper parts of the formation the macrofauna is unevenly distributed, but local accumulations of both brachiopods (spiriferids) and bryozoans (stenoporid trepostomes and fenestrates) are common. Infaunal trace fossils occur uniformly in the dark cherty shales.

The Kim Fjelde Formation was deposited on a marine carbonate shelf. The age ranges from Late Pennsylvanian (Late Virgilian?), established for the lower $20 \mathrm{~m}$ by Petryk (1977), to well into the Early Permain as witnessed by the brachiopod faunas from the dark, fine-grained limestones (F. G. Stehli, in Dawes, 1976).

\section{Trolle Land Group}

(map 1, fig. 26), new group

(Named after Herluf Trolle Land, eastern Peary Land)

The dominantly carbonate deposition which characterises the Mallemuk Mountain Group occurred throughout the Wandel Sea Basin, but the subsequent clastic Permo-Triassic units have so far been recorded only in eastern Peary Land. Here a more than $1000 \mathrm{~m}$ thick sequence spanning the Permian-Triassic boundary may be regarded as a series of three somewhat uniformly developed upwardly coarsening successions, each of which is designated a formation.

\section{Midnatfjeld Formation}

(fig. 26), new formation

(Named after a mountain called 'Midnatfjeld' in Kim Fjelde)

The Midnatfjeld Formation probably overlies the rock of Kim Fjelde Formation conformably. It begins with a unit up to $100 \mathrm{~m}$ thick of dark, calcareous shale which is sometimes heterolithic and, particularly in the upper part, contains a rather sparse marine fauna comprising productid and spiriferid brachiopods, as well as siliceous sponges. An overlying light weathering unit consists of up to $150 \mathrm{~m}$ of light grey-brown, generally fine-grained sandstone with isolated but prominent beds of grey limestone and light chert, particularly in the lower part. In addition, a fairly thin bed of pebbly conglomerate occurs towards the top. The uppermost part of the formation is an approximately $30 \mathrm{~m}$ thick unit of alternating very fine-grained, calcareous sandstones and shales that forms a very characteristic, yellow weathering unit.

Highly diversified marine faunas occur at various levels throughout the sandy sequence, in particular in the uppermost unit where productid and spiriferid brachiopods as well as fenestrate and stenoporid bryozoans dominate. Initial palynological results indicate that at least part of the formation is Lower Permian (B. Balme, personal communication 1979), while an Upper Permian fauna referred to by Dawes (1976) possibly originates from the uppermost unit of this formation. 


\section{Parish Bjerg Formation}

(Fig. 26), new formation

(Named after the mountain Henry Parish Bjerg in Kim Fjelde)

The Parish Bjerg Formation comprises more than $300 \mathrm{~m}$ of sandstones, shales, and conglomerates which apparently overly the Midnatfjeld Formation with a slight angular unconformity. Three units may be recognised. A distinctive basal unit approximately $35 \mathrm{~m}$ thick consisting of well sorted, reddish weathering sandstone alternating with light, pebbly conglomerates initiates the formation everywhere. Planar cross-bedding is often discernible where the conglomerates locally show a more sandy development. Bedding planes in the interbedded red sandstones show ripple marks and parting lineation. The middle part of the formation is composed of approximately $100 \mathrm{~m}$ of very poorly exposed, dark heterolithic shales. The upper $170 \mathrm{~m}$ of the formation are dominated by fine-grained, well sorted sandstones with prominent lenses of ferruginous, pebbly conglomerate.

Neither trace fossils nor body fossils have been recorded from either of the two lower units. In contrast, well preserved trace fossils indicative of shallow marine conditions (e.g. Rhizocorallium) are abundant at certain levels in the upper sandy unit. A single mould of a euomphalid gastropod (J. S. Peel, personal communication, 1979) constitutes the entire macro-fauna known from the Parish Bjerg Formation. Palynological investigations by B. Balme, personal communication, 1979) indicates a Triassic age for at least part of the formation.

\section{Dunken Formation}

(map 1, fig. 26), new formation

(Named after a mountain called 'Dunken' in Kim Fjelde)

The Dunken Formation is apparently restricted to an isolated, small fault block in the eastern part of Kim Fjelde where perhaps more than $600 \mathrm{~m}$ of gently dipping rocks are exposed. However, in spite of its very limited distribution, this formation is comparatively well known from two previously described profiles (Troelsen, in Kummel, 1953; Håkansson \& Heinberg, 1977). It is therefore only briefly described here. The lower recessive part is composed mainly of silty and sandy shales, whereas the upper part is dominated by fine-grained, well sorted sandstones which are often moderately to strongly bioturbated. Throughout the series comminuted carbonaceous debris is common, either evenly dispersed or sometimes concentrated in discrete drapes and partings.

A fauna comprising crinoids, brachiopods, pelecypods, ammonites, and fish occurs at a number of levels in the lower half of the formation. In the lower, shaly part the faunas indicate an Early Triassic (Scythian) age, whereas the ammonite fauna higher in the section indicates a Middle Triassic (Anisian) age (Kummel, 1953). From comparison with Canadian occurrences this ammonite fauna is thought to belong most likely to the lowermost Anisian zone (Håkansson \& Heinberg, 1977). In the upper part of the formation a single vertebra of an ichtyosaur (N. Bonde, personal communication, 1978) is the only fossil found so far, hence very little can be said about the age here.

Although plant remains have been reported (Peel et al., 1974; Dawes, 1976) there is little evidence to support the suggestion that the lower, shaly part of the Dunken Formation is any less marine than the upper sandy part (Dawes, 1976). On the contrary in view of both the 
body fossils and the trace fossils, the entire sequence recorded from the Dunken Formation appears to represent a fully marine environment (Håkansson \& Heinberg, 1977).

Neither the lower nor the upper boundary of the Dunken Formation are known.

\section{Ladegårdsån Formation}

(map. 1, fig. 26), new formation

(Named after the stream Ladegårdsåen draining the southern part of Kim Fjelde)

The Ladegårdsåen Formation comprises more than $200 \mathrm{~m}$ of flat-lying, poorly exposed sands and sandstones distributed along the southern margin of Kim Fjelde. The formation rests on an erosional surface exposing a variety of rocks ranging from Silurian turbidites to the Parish Bjerg Formation.

Two main areas of outcrop have been delimited. These display somewhat different lithological sequences. Locally, at least, the lowest beds of the formation consist of shallow pockets of a highly fossiliferous conglomerate with abundant belemnites. These rapidly give way to a unit comprising weakly cemented, fine-grained sands or sandy shales. Calcareous concretions are abundant and, in restricted horizons, they contain dense faunas dominated by pelecypods and scattered ammonites, in addition to widespread carbonised wood.

The middle part of the formation is composed of prominent fine- to coarse-grained sandstones which are generally poorly sorted and, in their lower part, often vividly coloured in shades of red, brown and orange. The sandstones are composed mainly of planar cross-bedded sets a metre or more in thickness, typically with a southerly foreset dip. Calcite cementation is widespread in this unit, commonly destroying completely the initial porosity.

The upper unit is very poorly exposed. It is generally developed as soft, fine-grained sands, byt occasional coarser beds occur. Comminuted carbonaceous material is widespread and commonly concentrated in heterolithic intervals in otherwise homogeneous sand. The only macrofossils found are fragments of iron-impregnated wood.

The faunal distribution and the lithological development suggest that the deposits of the Ladegårdsåen Formation represent a gradual transition from marine to limnic conditions. Initial results from faunal and microfloral investigations indicate that this transition spans at least the period from Early Volgian to Rhyazanian (T. Birkelund and S. Piasecki, personal communication, 1979).

\section{Nakkehoved Formation}

(map 1), new formation

(Named after the semi-nunatak Nakkehoved on the north coast of Kronprins Christian Land)

The Nakkehoved Formation is a highly monotonous series of dark grey to almost black, fine-grained sandstones. It outcrops in the nunataks and semi-nunataks along the north coast of Kronprins Christian Land where the composite thickness is estimated to exceed 600 $\mathrm{m}$. A section covering $300 \mathrm{~m}$ in the lower part of the sequence was measured in detail. The sandstones are homogeneous, dominated by angular quartz grains with subordinate feldspar grains, and typically contain a high amount of matrix. This matrix usually contains a significant proportion of amorphous coal. The few coarser beds with a smaller proportion of matrix typically have their initial porosity obliterated due to quartz cementation.

The macrofauna is scarce and of very low diversity. Protobranch pelecypods (nuculoids) 
are dominant, but also a few specimens of a posidoniid pelecypod resembling Didymotis have been provisionally determined (C. Heinberg, personal communication, 1978). In addition, thin tubular burrows occur at most levels. Deposition probably took place in a somewhat restricted marine environment, where a muddy bottom rich in organic material supported a restricted deposit-feeding community.

Nielsen (1941) recorded two additional sections in the Nakkehoved region but with little lithological detail. On the basis of the not very well preserved fauna he suggested a Late Cretaceous to Early Tertiary age for the rocks. The presence of posidoniids in the fauna supports a Late Cretaceous rather than Tertiary age.

\section{Herlufsholm Strand Formation}

(map 1, fig. 26), new formation

(Named after the broad low plain bordering Kim Fjelde towards the north-east)

The Herlufsholm Strand Formation has only been recorded in the structurally most complex fault block in eastern Peary Land where two main rock suites have been investigated. Together these two suites comprise $435 \mathrm{~m}$, but the relation between them has so far been assessed only from structural analysis.

The lower third of the formation is characterized by rapidly alternating, distinct thin beds of silty to coaly shales, partly heterolithic sandstones, and greywackes with occasional wood impressions. The shales are black with abundant, poorly preserved plant remains and usually contain a very high proportion of organic detritus. The upper two-thirds of the formation are dominated by rather poorly sorted, cross-bedded sandstones, with some fine-grained, dark sandstones with thin silty partings. Wood impressions are fairly abundant in the cross-bedded sands, while indistinct bioturbation is commonly visible in the fine-grained rocks.

The Herlufsholm Strand Formation is characterised by rapid vertical facies changes. However, a partial result of the deformational overprint is that very little is known about the lateral variation and, thus, about the depositional environment. A general trend from a limnic to a near coastal, marine phase seems probable. The Late Cretaceous to Early Tertiary age suggested by Troelsen (1950), was apparently based on a loose fragment of (angiosperm?) wood. However, more precise age determinations are still lacking.

Neither the lower nor the upper boundary of the formation has been observed.

\section{Thyra $\emptyset$ Formation}

(map 1), new formation

(Named after the island Prinsesse Thyra $\emptyset$ between Peary Land and Kronprins Christian Land)

The Thyra $\varnothing$ Formation is composed of soft, very poorly exposed shaly heteroliths and fine-grained sandstones with occasional, thin seams of shiny, homogeneous coal. Only $35 \mathrm{~m}$ have been recorded in a section, but previous investigations on Prinsesse Thyra $\varnothing$ by the Greenarctic Consortium (in Dawes, 1976) have established the presence of more than 100 $\mathrm{m}$ of largely similar rock. At some levels weakly cemented concretions contain a fairly diverse flora of well preserved leaves from deciduous trees. Carbonised roots have been found in connection with one of the coal seams.

Obvious cyclic development is not apparent in the distribution of the sedimentary facies and, for the most part, the sequence was probably deposited in a limnic environment on a 
broad, low plain. However, in spite of the impression given by the sedimentary facies, some marine influence is evident from the presence of dinoflagellate cysts at some levels. (C. Croxton, personal communication, 1979).

According to Greenarctic Consortium (in Dawes, 1976) the leaves are comparable to species from the Eureka Sound Formation in Ellesmere Land (Arctic Canada) and suggest a Paleocene age.

Nothing is at present known about the lower or upper boundaries of the Tyra $\varnothing$ Formation. In addition to the nominal area it is known to occur only on Prinsesse Dagmar $\varnothing$, whereas an apparently continuous Quaternary cover makes the presence on Prinsesse Margrethe $\varnothing$ uncertain.

\section{Structures}

Structurally the northern part of the Wandel Sea Basin is dominated by a system of major NW-SE trending faults (Dawes, 1976) which parallel the de Geer fracture zone separating northern Greenland from Svalbard (Harland, 1969; Birkenmajer, 1972). Being situated more or less at the 'hinge', the deformational history discernible in the Wandel Sea Basin may therefore contribute to the understanding of the early spreading history of both the extreme North Atlantic and the Arctic Ocean. In this connection it is important to note that no sign of magmatic activity has been found in the Wandel Sea Basin. However, at present only a few notes on the deformational sequence and the basin history in eastern Peary Land will be presented.

Prior to the establishment of the Wandel Sea Basin regional folding and faulting affected the entire area now underlying Wandel Sea Basin sediments in Peary Land. The upper age limit of this deformation is determined by the Upper Carboniferous Foldedal and Kim Fjelde Formations which overlie the Franklinian rocks with a regional unconformity (Troelsen, 1950). Clear evidence of metamorphism influencing Franklinian rocks was recorded only near Frederick E. Hyde Fjord, some distance north of the present limit of the Wandel Sea Basin sediments. Here the regional trend in well developed slaty cleavage in refolded greenschists was found to parallel the major faults mentioned above.

The apparent slight angular unconformity between the Midnatfjeld Formation and the Parish Bjerg Formation seems to indicate minor movements of probably Late Permian age. Similarly the angular unconformity at the base of the Upper Jurassic Ladegårdsåen Formation in part of the area indicates that some movement took place prior to the Late Jurassic. Whether these movements belong to the same deformation phase remains unsettled, but the discussion below suggests that they probably represent separate phases.

Following the termination of the Wandel Sea Basin sedimentation now recorded in Peary Land the entire area was dissected by the major NW-SE trending faults (fig. $26 \mathrm{~A}$ ). In the resulting system of fault blocks drag directions and age relations across faults give seemingly contradictory displacement directions (fig. $26 \mathrm{~B}$ ). Somewhat comparable structural relations in the European Jura Mountains have been attributed to a tensional phase which caused the faulting followed by a compressional phase which gave rise to small associated folds (Glangeaud, 1950). In Peary Land this explanation is supported by the more extensive folding also seen in rocks of the Herlufsholm Strand Formation, but here the reverse sequence of events seems equally plausible. However, as the fold crest zones trend approximately $110^{\circ}$, i.e. at an angle to the general fault direction, it may be suggested that the fault system 


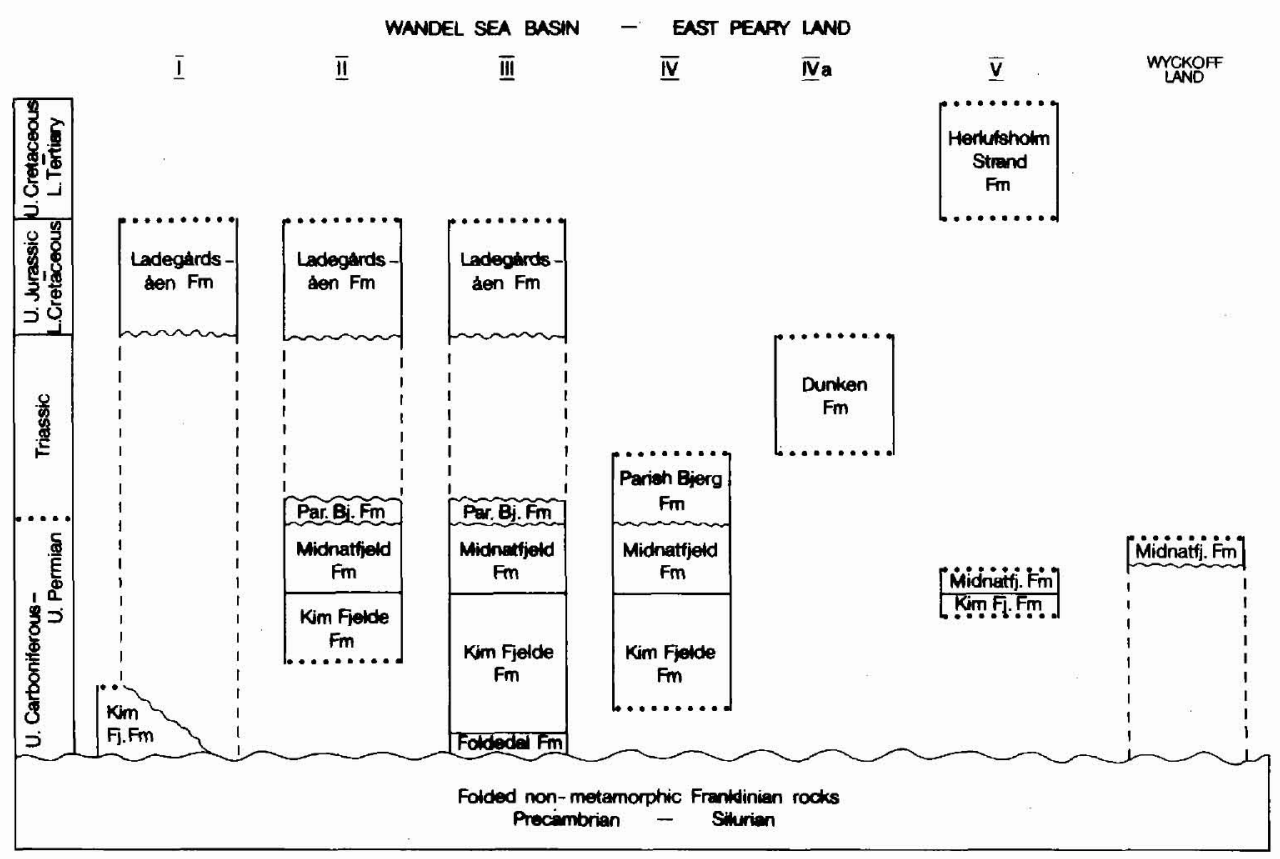

Fig. 27. Lithostratigraphic composition of the major fault blocks in eastern Peary Land (Roman numerals refer to fig. 26A).

was established prior to the post-Paleocene tectonics and was merely reactivated by the later stress, in spite of a change in the stress axes. The isolated thick Triassic sequence of the Dunken Formation (fig. 27) may indicate that such an early phase took place in the Jurassic before the Volgian transgression.

The magnitude of the lateral displacements between the fault blocks in individual phases is difficult to ascertain and, at present, only little can be said about the composite displacement. However, the net displacement in the system is substantial, as illustrated by the present distribution of the Foldedal Formation at the border between fault block II and III. Here, the estimated movement with a lateral sinistral component in the order of $2.5 \mathrm{~km}$ is perhaps only a minimum value.

\section{References}

Birkenmajer, K. 1972: Tertiary history of Spitsbergen and continental drift. Act. geol. Polonica 22, 2, 193-218.

Dawes, P. R. 1976: Precambrian to Tertiary of northern Greenland. In Escher, A. \& Watt, W. S. (edit.) Geology of Greenland, 249-303. Copenhagen: Geol. Surv. Greenland.

Dawes, P. R. \& Soper, J. 1973: Pre-Quaternary history of North Greenland. Mem. Am. Ass. Petrol. Geol. 19, 117-134.

Frebold, H. 1950: Stratigraphie und Brachiopodenfauna des marinen Jungpaläozoikums von Holms und Amdrups Land (Nordostgrönland). Meddr Grønland 126, 3, 97 pp. 
Glangeaud, L. 1950: Le rôle du socle dans la tectonique du Jura. Ann. Soc. Géol. Belgique 73, 57-94. Grönwall, K. A. 1917: The marine Carboniferous of North-East Greenland and its brachiopod fauna. Meddr Grønland 43, 20, 509-618.

Harland, W. B. 1969: Contribution of Spitsbergen to understanding of tectonic evolution of North Atlantic Region. Mem. Am. Assoc. Petr. Geol. 12, 817-851.

Håkansson, E. \& Heinberg, C. 1977: Reconnaissance work in the Triassic of the Wandel Sea Basin, Peary Land, eastern North Greenland. Rapp. Gronlands geol. Unders. 85, 11-15.

Koch, L. 1929a: The geology of East Greenland. Meddr Grønland 73 (2), 1, 204 pp.

Koch, L. 1929b: Stratigraphy of Greenland. Meddr Grønland 73 (2), 2, 205-320.

Kummel, B. 1953: Middle Triassic ammonites from Peary Land. Meddr Grønland 127, 1, 21 pp.

Nielsen, E. 1941: Remarks on the map and the geology of Kronprins Christians Land. Meddr Grønland 126, 2, $35 \mathrm{pp}$.

Peel, J. S., Dawes, P. R. \& Troelsen, J. C. 1974: Notes on some Lower Palaeozoic to Tertiary faunas from eastern North Greenland. Rapp. Grønlands geol. Unders. 65, 18-23.

Petryk, A. A. 1977: Upper Carboniferous (Late Pennsylvanian) microfossils from the Wandel Sea Basin, Peary Land, eastern North Greenland. Rapp. Grønlands geol. Unders. 85, 16-21.

Troelsen, J. [C.] 1950: Geology. In Winther, P. C. et al. A preliminary account of the Danish Pearyland Expedition, 1948-9. Arctic 3, 6-8.

Troelsen, J. C. 1956: The Cambrian of North Greenland and Ellesmere Island. In El sistema Cambrico, su paleogeografía y el problema de su base. 20 Congr. geol. int. Mêxico. Symp. 3, (1), 71-90. 